\section{MORAL FOUNDATIONS OF WELFARE ATTITUDES: THE ROLE OF MORAL INTUITION AND REASONING IN PURSUING SOCIAL JUSTICE}

\section{Andrej Findor ${ }^{1}{ }^{2}$}

Comenius University in Bratislava

Abstract: The article interconnects the research on welfare attitudes and welfare chauvinism with moral psychology in order to develop an interdisciplinary analytical approach designed for studying attitudes to welfare policies and potentially overcoming the divisions prevalent in many European democracies. It introduces Moral Foundations Theory (MFT) - an empirical approach to analysing intuitions, reasoning, and emotions constituting moral judgment - and outlines its understanding of competing versions of fairness and distributive justice. The potential contributions of MFT are exemplified on a case study situated in contemporary Slovakia which deals with two conflicting conceptions of fairness, as equity and as equality, embodied in the diverging attitudes towards an amendment to the Act on the Assistance in Material Need (2013). The article argues that MFT and related research programmes are irreplaceable components in an interdisciplinary study of the plurality of welfare policy attitudes. It also highlights the transformative potential of MFT and related research programmes in devising interventions aimed at changing (political) attitudes to welfare and reducing their polarisation.

Keywords: welfare attitudes, moral judgement, intuition, reasoning, fairness, equality, equity, Moral Foundations Theory

ANDREJ FINDOR - Comenius University in Bratislava, Faculty of Social and Economic Sciences•findor@fses.uniba.sk

1 This article is a result of a research project supported by the Ministry of Education of the Slovak Republic under the APVV grant scheme, no. APVV-0880-12, "Knowledge utilization in the production of policy documents in the policy-making process".

2 This article is a result of a project "Extremist breakthrough in the low turnout elections: A lasting momentum?", supported by a grant from the Foundation Open Society Institute in cooperation with the Open Society Initiative for Europe of the Open Society Foundations.
Central European Journal of Public Policy

Vol. 9 - № 2 - December 2015 - pp 72-95

ISSN 1802-4866

() 2015 Andrej Findo

Licensed under Creative Commons Attribution 3.0

\section{INTRODUCTION}

Attitudes to welfare policies divide populations in many European countries. The main aim of this article is to develop an interdisciplinary analytical approach to studying these polarising differences in public opinion and overcoming their destructive divisiveness, which can potentially fuel the agenda of extremist political programmes. The article brings together, at the conceptual level, two interdisciplinary approaches - welfare attitudes research and moral psychology, which continue to ignore each other's findings although there is much they can learn from each other. Welfare is a multifaceted term and plays a crucial role in many research programmes in a variety of social science disciplines. As Bent Greve rightly notes, understanding welfare "in terms of just one discipline would, therefore, be to overlook central aspects of the concept" (Greve, 2008)

Thus, in the first part of the article, I focus on welfare attitudes research, including that on welfare chauvinism. Its useful analytical tools made it possible to approach the study of attitude formation, reproduction and change concerning welfare and social policy preferences in a systematic, comprehensive manner. It made operational the assumptions on reciprocity, as the main underlying characteristic of fairness, by relating them to a fair distribution of resources in various welfare regimes.

The concept of reciprocity has created a suitable point of entry for introducing the Moral Foundations Theory (MFT), which I am going to develop in the second part of the article. MFT is analytically equipped to refine our understanding of reciprocity and its relationship to deservingness, proportionality and equity as some of the dominant concepts of fairness. ${ }^{3}$ I am going to argue that analysing the moral foundations of welfare attitudes and preferences, and especially equity and equality as the main competing versions of fairness, brings novel insights into the processes of constitution and reproduc-

3 An attempt to establish a connection between two different interdisciplinary endeavours (such pplied behavioural science, increasingly takes the position policy makers and public policy researchers (Shafir, 2013). 
tion as well as into the variability and malleability of the divided and polarised public opinion on welfare. I am going to exemplify the usefulness of this type of insight on data collected in Slovakia. I will demonstrate the analytical instrumentality of MFT by linking together the attitudes towards a contested welfare provision (e.g., the revised Act on Assistance in Material Need), the variable moral foundations of its supporters and opponents and their conflicting intuitions about fairness as equity and equality.

Although the divisiveness and polarising potential of conflicting welfare attitudes and preferences is an established empirical fact, it can nevertheless be overcome. Thus, in the last part of the article, I am going to introduce MFT's potential added value - its yet-to-be-tested transformative potential in shifting policy attitudes (including ones toward welfare and redistribution) and in reducing the polarisation of policy preferences.

\section{WELFARE ATTITUDES AND WELFARE CHAUVINISM}

The study of moral beliefs and values conditioning the attitudes towards and policies of the welfare state could be, with a certain degree of simplification divided into two main types. First, the normative type focuses on underlying moral principles of welfare states in order to find the hidden philosophical and ethical roots of their economic and social order, so that principles of justice and fairness could be thoroughly applied therein (Frey \& Morris, 1993; Shionoya 2005). Second, the empirical type describes the structural, collective and in dividual determinants of attitudes towards welfare policies, with morality being one of the key explanatory factors in this complex relationship (Mau, 2003) Since the cross-country differences in welfare attitudes cannot be conclusively explained by national welfare regimes (Arts \& Gelissen, 2001), researches have focused on finding the plausible explanations in other related factors. A wealth of welfare attitudes research has posited that critical attitudes towards the welfare state centre around negative views on mis-targeted welfare benefits, and more particularly high levels of overuse, misuse or fraud (benefit abuse) as well as underuse (non-take-up) thereof (Edlund, 1999; Ervasti, 2012).

Femke Roosma and her colleagues consider the administrative failure and the moral failure in the mis-targeting of welfare benefits as the "weakest link in welfare state legitimacy" (Roosma, van Oorschot, \& Gelissen, 2014). Negative beliefs about overuse and underuse of welfare assistance stem from critical perception of moral failure and failed administrative implementation. Authors distinguish between substantive justice, which refers to basic legit imacy of the welfare state (there is a public support for welfare programmes, which are considered to be fair and just), redistributive justice, conceived as the fair redistribution of contributions to the welfare programmes, and procedural justice - "effective and efficient implementation of welfare policies" (Roosma, van Oorschot, \& Gelissen, 2014, p. 490). Analysing data from European Social Survey, Round 4, 2008/2009 ( 25 countries, $n=47,489$ ), they came to the conclusion that "underlying attitudes toward mis-targeting can best be captured in one normative factor that expresses perception of moral flaws of benefit recipients" and one administrative factor representing "perceptions of administrative failure or an ineffective targeting by the welfare state" (Roosma, van Oorschot, \& Gelissen, 2014, p. 504). Normative perceptions of mis-targeting are related to structural position - higher levels of employment, health, and satisfaction with income correlate with lesser normative perceptions of benefit abuse; and to political ideology - supporters of right-wing political parties and movements tend to be more critical of intentional benefit abuse (Roosma van Oorschot, \& Gelissen, 2014, p. 500). Jeroen van der Waal and his colleagues reached a similar conclusion, finding out that the difference in support of welfare-chauvinistic attitudes between liberal, conservative and social-democratic welfare regimes can be more readily attributed to the differences in their income inequality (van der Waal, de Koster, \& van Oorschot, 2013).

In contrast, Nam K. Jo, when inspecting the cultural foundations of welfare attitudes, came to a different set of conclusions. According to Jo, the variance in answers to the notorious moral question of welfare policy, "who should get, what and why?", cannot be satisfactorily explained without taking culture seriously. Jo conceives "culture" as a set of trans-situational and "dynamically stable" societal values set in "between concrete public opinion and abstract basic human values" (Jo, 2011, p. 8). These societal values - religiosity (religious beliefs and church attendance), traditional ethical values (continuity of society and the existing social order), legal permissiveness, tolerance (basis of solidarity, cooperation and social cohesion), traditional family values, and optimism - create a cultural context for welfare policies. Societal values come close to what Clem Brooks and Jeff Manza termed as embedded preferences. These preferences about social welfare are complementary factors to economic calculations and business cycle development because they are "organized by reference to the social relations and contexts in which individuals are situated. Citizens' identities, for example, as business managers, lone parents, or doctrinally conservative Christians matter to their policy attitudes." (Brooks \& Manza, 2007, p. 8) Drawing on data from the European Values Survey and the World Values Survey of 1990 and 1999/2000, Jo found out that victimblaming perceptions of poverty (respondents choosing "laziness and lack of willpower" as the main reason for people's poverty) have a strong positive re- 
lationship with religiosity and traditional ethical values, and a strong negative relationship with tolerance (Jo, 2011, pp. 12-13).

In a similar vein, Daniel Stegmueller and his colleagues attempted to find out whether religion (religious attendance and denomination) determines at titudes towards income redistribution by the state. Analysing the European Social Survey 2002-2006 cumulated data set ( $n=79,679,16$ countries), they concluded that both Catholics and Protestants strongly oppose redistribution but the strongest effect is not conditioned by church attendance or denomination per se but by the cleavage between religious and secular individuals (Stegmueller, Scheepers, Rossteutscher, \& de Jong, 2011). Recognising the Janusfaced nature of religion as social glue and source of conflict and disagreement historically manifested in the state-church competition, Stegmueller and his colleagues conclude that the more polarized the religious/secular division becomes, the lower the popular support for redistribution by the state ensues (Stegmueller, Scheepers, Rossteutscher, \& de Jong, 2011).

The recent decades have seen a rise in critical attitudes towards welfare state assistance provisions and some of its recipients, which (in relevant academic literature) are referred to as welfare chauvinism. In Western Europe, immigrants or citizens of foreign descent became the so-called "new undeserving poor" - considered to be less deserving of welfare state assistance as the native born, elderly, disabled and unemployed (Bommes \& Geddes, 2000 van Oorschot, 2006). Populist political parties in Western Europe increasingly adopt welfare-chauvinistic positions, criticizing mainstream parties for supporting "undeserving" immigrants at the expense of "native" populations, whose decades-old welfare certainties are being reduced and redefined (Schumacher \& van Kersbergen, 2014). Although there is great variance between individual cases, the general pattern speaks of gradual adoption of the welfare-chauvinistic political agenda by mainstream political parties (Schumacher \& van Kersbergen, 2014). These negative attitudes can be viewed as part of a broader opposition among European populations to granting civi rights to legal immigrants - a phenomenon of ethnic exclusionism explained by perceived ethnic competition, as posited by the Ethnic Competition Theory (Scheepers, Gijsberts, \& Coenders, 2002). It is important to add that in many countries of Central and Eastern Europe, where the immigration rates come nowhere close to the ones in Western Europe, a different population category became the sole target of welfare-chauvinistic attitudes - the Roma (Stew art, 2012). From the American point of view, other authors refer to the spread of welfare-chauvinistic agendas as "playing the race card", which seems to equally befit of the Central and Eastern European context in which the "racialized" ethnicity of Roma populations plays an important part in the for- mulations and attitudes supporting the welfare-chauvinistic political agendas (Schmidt \& Spies, 2014).

Researchers usually distinguish between two basic types of welfare chauvinism: soft chauvinism, based on beliefs about lesser deservingness of immigrants compared to native citizens, and strict chauvinism, informed by an opinion that immigrants should be excluded from any welfare state provision (Svallfors, 2012a). Tim Reeskens and Wim van Oorschot refer to problems with finding popular support for welfare programmes that have been introduced in the times of cultural homogeneity as a "New Liberal Dilemma" (Reeskens \& van Oorschot, 2012). Analysing the data from the fourth wave (2008/2009) of the European Social Survey they found weak support for the strict version of welfare chauvinism and strong support for its soft version conditional access to welfare state provision only after becoming citizen, being employed and paying taxes. This "merit" principle remained significant event after the authors controlled for the varying diversity of populations in the 27 European countries compared. ${ }^{4}$ The finding that "the idea of reciprocity - that one should first make contributions to the welfare state before having entitlements - is less affected by immigration" points in the direction of fairness understood as equity: reciprocal and proportional cooperation of more-or-less equal actors (Reeskens \& van Oorschot, 2012, p. 132).

The concept of reciprocity helps us to understand how the expansion or contraction of the redistributive role of the state comes about, providing us with insight into the motivational predispositions of attitudes to welfare policies (León, 2012). Borrowing the model of homo reciprocans from experimental economics, Francisco José León set out to explore how the feelings of reciprocity and associated norms influence the popular support for the redistributive role of the state. Using two ordinary least squares (OLS) regression models on data acquired by the fourth round of the European Social Survey in 2008 ( $n=35,368,22$ countries), León clearly demonstrated that variables associated with "reciprocity" are better predictors of support for the redistributive policies of welfare states than the ones associated with self-interest (the key concept of the homo oeconomicus model) (León, 2012). The homo reciprocans operates on the assumption that fairness and reciprocity are fundamental motivators of human behaviour. ${ }^{5}$ Summing up the wide array of experimental research, León provides a set of basic traits of homo reciprocans:

4 A low significance of ethnic diversity in explaining varying degrees of welfare chauvinism was also corroborated in another study (van der Waal, de Koster, \& van Oorschot, 2013).

5 This claim is supported by research findings in evolutionary psychology and hunter-gatherer studies (Petersen, Sznycer, Cosmides, \& Tooby, 2012). 
"(a) She favours the distribution of goods geared at meeting basic needs.

(b) She is generous but her generosity is conditional.

(c) She favours recipients of help who are considered to be 'deserving'. What makes people deserving is: (1) previous contributions, especially effort and social valued work, (2) not being responsible for their own needy situation, and (3) their capacity to arouse a well-grounded expectancy on their kindness in future interactions.

(d) She cooperates with those who also cooperate. She reacts against those who violate cooperative norms.

(e) She cares about the fairness of the process and the result of redistribution.

(f) She is committed to a balance between burdens and rewards in social exchange, which leads her to meritocracy, but usually takes equal division as a reference point too.

(g) Experimental results also point to a more problematic feature of the homo reciprocans model: all these tendencies correlate strongly and negatively with the social distance between interacting individuals." (León, 2012, pp. 200-201, italicized by the journal)

The concept of homo reciprocans sheds light on the role of fairness and reciprocity in creating psychological motivations, which consequently become represented in (chauvinistic) welfare attitudes. In order to account for the sheer empirical variety of "fairness" - why different people, groups and institutional environments may perceive and utilise fundamentally different versions of fairness and related notions of social (distributive) justice - I must turn to empirical moral psychology, or more concretely to Moral Foundation Theory. Moreover, keeping in mind that various above-mentioned scholars identified income inequality, religiosity, traditional ethical values, political ideology, and cleavages between religious and secular worldviews as powerful factors related to welfare attitudes, it might be revealing to find out whether these relationships can be further illuminated by moral psychological research and such findings can be effectively translated into impactful interventions.

\section{FAIRNESS AS EQUITY AND EQUALITY IN \\ MORAL FOUNDATIONS THEORY}

The study of morality in political science and other social sciences has long been approached in a normative fashion. Its explicit prescriptive orientation was conveyed in questions such as "What is a right thing to do for a public official to remain impartial?" or "What should fair distribution of public resources be like?" (Rawls, 1971). In contrast, the moral psychology approach I am going to introduce has a clear descriptive focus. Instead of asking what is right, fair or just, it concentrates on the individual (and less often group and societal) level of variance in moral convictions and values. A simple observation that various people moralize in different ways led to the development of a number of theories and measures which could capture the observed differences in moral judgments and moral reasoning (Sinnott-Armstrong, 2008).

Arguably the most prevalent approach nowadays for measuring the individual-level differences in moral judgements is the Moral Foundation Theory (MFT). Developed by Jonathan Haidt and Craig Joseph in 2003, MFT had devised a Moral Foundations Questionnaire, a validated measurement tool for variances in moral judgement with a significant ability to predict political attitudes and ideological positions (Haidt \& Joseph, 2004; Haidt, Graham, \& Joseph, 2009; Iyer, Koleva, Graham, Ditto, \& Haidt, 2012; Koleva, Graham, Iyer Ditto, \& Haidt, 2012). I am going to introduce two metaphors borrowed form Haidt, which should make the following brief characterisation of MFT readerfriendly and comprehensible to the degree required for the purpose of this article.

The first metaphor, which likens moral foundations to taste buds, explains the plurality of moral judgements. Human beings share the same taste buds to establish the taste of the food they consume. There are five basic gustatory sensations (tastes) - sweet, salty, sour, bitter, and savoury. Yet the food we consume is by no means subject to one universal gustatory standard. A soup one finds too salty is not salty enough for another and as human beings organised in groups we even developed cuisines to establish vernacular gustatory standards, which are often quite different from those of our "next-door" (tribe, country) neighbours. Roughly the same applies to our moral tastes or moral judgements. We refer to the same concepts but our perceptions and justifications behind them can be strikingly different. Since the variety of moral judgements can exist at individual, collective and even mass-scale level, there are number of psychical, physical, relational, organizational and environmental factors which might explain it (Haidt, 2012). Haidt introduced the so-called social intuitionist model (SIM) to account for the role played by our innate moral 
intuitions and external social factors shaping our moral judgements (Haidt 2013a). Together with colleagues, Haidt developed the Moral Foundations Questionnaire (MFQ) to measure the individual variance in five moral foundations: care/harm, fairness/cheating, loyalty/betrayal, authority/subversion, and sanctity/degradation (Graham et al., 2011; Graham, Haidt, et al., 2013). ${ }^{6}$ As Table 1 indicates, each moral foundation has its evolutionary roots, which became adapted for a current set of cultural triggers and which are accompanied by a relevant set of emotions. Amassing a vast amount of data, Haidt and his colleagues were able to relate the moral foundations of respondents to their religious beliefs, political attitudes, and ideological preferences (Iyer, Koleva Graham, Ditto, \& Haidt, 2012; Koleva, Graham, Iyer, Ditto, \& Haidt, 2012; Graham, Nosek, \& Haidt, 2012). They identified a "moral gap" between American liberals and conservatives (Ditto \& Koleva, 2011). Liberals responded more strongly than conservatives to questions related to the moral foundations of care/harm and fairness/cheating. On the other hand, conservatives scored significantly higher on the remaining three moral foundations of loyalty/betrayal, authority/subversion, and sanctity/degradation. Overall, American conservatives had higher total scores on all five moral foundations, which lead Haidt to conclude that in terms of value orientations there is a clearly discernible "conservative advantage" (Haidt, 2012).
Table 1 The five moral foundations

\begin{tabular}{|c|c|c|c|c|c|}
\hline & Care & Fairness & \multirow{2}{*}{$\begin{array}{l}\text { Loyalty } \\
\text { Betrayal }\end{array}$} & \multirow{2}{*}{$\begin{array}{l}\text { Authority } \\
\text { Subversion }\end{array}$} & \multirow{2}{*}{$\begin{array}{l}\text { Sanctity } \\
\text { Degradation }\end{array}$} \\
\hline & Harm & Cheating & & & \\
\hline $\begin{array}{l}\text { Adaptive } \\
\text { challenge }\end{array}$ & $\begin{array}{l}\text { Protect and } \\
\text { care for } \\
\text { children }\end{array}$ & $\begin{array}{l}\text { Reap benefits } \\
\text { of two-way } \\
\text { partnership }\end{array}$ & $\begin{array}{l}\text { Form } \\
\text { cohesive } \\
\text { coalitions }\end{array}$ & $\begin{array}{l}\text { Forge } \\
\text { beneficial } \\
\text { relationships } \\
\text { within } \\
\text { hierarchies }\end{array}$ & $\begin{array}{l}\text { Avoid } \\
\text { contaminants }\end{array}$ \\
\hline $\begin{array}{l}\text { Original } \\
\text { triggers }\end{array}$ & $\begin{array}{l}\text { Suffering, } \\
\text { distress, or } \\
\text { neediness } \\
\text { expressed } \\
\text { by one's } \\
\text { child }\end{array}$ & $\begin{array}{l}\text { Cheating, } \\
\text { cooperation, } \\
\text { deception }\end{array}$ & $\begin{array}{l}\text { Threat or } \\
\text { challenge } \\
\text { to group }\end{array}$ & $\begin{array}{l}\text { Signs of } \\
\text { dominance } \\
\text { and } \\
\text { submission }\end{array}$ & $\begin{array}{l}\text { Waste } \\
\text { products, } \\
\text { diseased } \\
\text { people }\end{array}$ \\
\hline $\begin{array}{l}\text { Current } \\
\text { triggers }\end{array}$ & $\begin{array}{l}\text { Baby seals, } \\
\text { cute cartoon } \\
\text { characters }\end{array}$ & $\begin{array}{l}\text { Marital fidelity, } \\
\text { broken vending } \\
\text { machines }\end{array}$ & $\begin{array}{l}\text { Sport } \\
\text { teams, } \\
\text { nations }\end{array}$ & $\begin{array}{l}\text { Bosses, } \\
\text { respected } \\
\text { professionals }\end{array}$ & $\begin{array}{l}\text { Taboo ideas } \\
\text { (communism, } \\
\text { racism) }\end{array}$ \\
\hline $\begin{array}{l}\text { Characteristic } \\
\text { emotions }\end{array}$ & Compassion & $\begin{array}{l}\text { Anger, } \\
\text { gratitude, guilt }\end{array}$ & $\begin{array}{l}\text { Group } \\
\text { pride, rage } \\
\text { at traitors }\end{array}$ & Respect, fear & Disgust \\
\hline $\begin{array}{l}\text { Relevant } \\
\text { virtues }\end{array}$ & $\begin{array}{l}\text { Caring, } \\
\text { kindness }\end{array}$ & $\begin{array}{l}\text { Fairness, } \\
\text { justice, } \\
\text { trustworthiness }\end{array}$ & $\begin{array}{l}\text { Loyalty, } \\
\text { patriotism, } \\
\text { self- } \\
\text { sacrifice }\end{array}$ & $\begin{array}{l}\text { Obedience, } \\
\text { deference }\end{array}$ & $\begin{array}{l}\text { Temperance, } \\
\text { chastity, piety, } \\
\text { cleanliness }\end{array}$ \\
\hline $\begin{array}{l}\text { Moral } \\
\text { Foundations } \\
\text { Questionnaire } \\
\text { (examples of } \\
\text { questions) }\end{array}$ & $\begin{array}{l}\text { It can never } \\
\text { be right to } \\
\text { kill a human } \\
\text { being. }\end{array}$ & $\begin{array}{l}\text { Justice is the } \\
\text { most important } \\
\text { requirement for } \\
\text { a society. }\end{array}$ & $\begin{array}{l}\text { I am proud } \\
\text { of my } \\
\text { country's } \\
\text { history. }\end{array}$ & $\begin{array}{l}\text { Respect for } \\
\text { authority is } \\
\text { something all } \\
\text { children need } \\
\text { to learn. }\end{array}$ & $\begin{array}{l}\text { People should } \\
\text { not do things } \\
\text { that are } \\
\text { disgusting, } \\
\text { even if no one } \\
\text { is harmed. }\end{array}$ \\
\hline
\end{tabular}

Source: Haidt (2012, p. 125). Bottom row was added by the author

The second metaphor explains the asymmetric relationship between intuition and reasoning in moral judgment. It speaks of an elephant and its rider in order to represent the duality of human cognition and moral judgement (Haidt, 2005). It identifies with dual process theories of cognition in recognising System 1 or intuition, which is automatic, uncontrolled, effortless, associative, fast, unconscious, and skilled; and System 2 or reasoning, which is reflective, controlled, effortful, deductive, slow, self-aware, and rule-following (Kahneman, 2011). The elephant replaces the horse as the usual riding animal in order
Haidt and his colleagues later devised a sixth moral foundation - liberty/oppression, which was supposed to explain the juxtaposed understandings of fairness. I will pay attention to this issue in the upcoming section 
to highlight the fact that human judgement is largely intuitive and that reasoning only comes second. According to Haidt's model, when confronted with an opportunity for moral judgement, we arrive instantly at most of our judgements by intuition and only afterwards employ moral reasoning in the form of ex-post justifications (Haidt, 2005; Haidt, 2012).

The presumed dominance of intuition over reasoning in moral judgement became the subject of fierce criticism (Greene, 2013; Bloom, 2013), which I am going to introduce in greater detail in the last section. In the upcoming sections I am also going to argue that moral foundations are not only valuable analytica tool for understanding the underlying mechanisms of the formation of political attitudes (including welfare attitudes), but can also the become potential basis for an effective shifting of these attitudes.

In order to exemplify how instrumental the knowledge about moral foundations can become for a more insightful understanding of the roots of divisive and conflicting welfare policies, I turn to research conducted by me and my colleagues. In autumn 2013, we set out to explore the moral foundations of the so-called general public in Slovakia and of representatives of Slovak nongovernmental organisations (NGOs) which pursue human rights agendas (Fin dor, Mad’arová, \& Ostertágová, 2015). The sample included 298 respondents, 77 from NGOS and 221 from general public. Table 1 contains a basic description of the sample.

Table 2 The moral foundations of the general public and NGOs in Slovakia

\begin{tabular}{lccllll}
\hline & Age & \multicolumn{5}{c}{ Gender } \\
\hline & Min. & Max. & $\begin{array}{l}\text { M } \\
\text { (SD) }\end{array}$ & Women & Men & Other \\
\hline Total & 18 & 74 & $\begin{array}{l}38.8 \\
(-12.6)\end{array}$ & $57 \%$ & $43 \%$ & $0 \%$ \\
\hline $\begin{array}{l}\text { General } \\
\text { Public }\end{array}$ & 18 & 74 & $\begin{array}{l}40.5 \\
(-0.9)\end{array}$ & $52 \%$ & $48 \%$ & $0 \%$ \\
\hline NGOs & 22 & 61 & $\begin{array}{l}33.9 \\
(-1.1)\end{array}$ & $71 \%$ & $28 \%$ & $1 \%$ \\
\hline M-mean; SD - standard deviation & & & & \\
\hline
\end{tabular}

Source: Findor, Mad'arová, \& Ostertágová (2015)

We utilised a Slovak version of the Moral Foundations Questionnaire (MFQ) which we had developed earlier (Findor, Mad’arová, \& Ostertágová, 2014). The respondents answered 6 questions related to each moral foundation using a six-point scale, where a higher score indicates stronger sensibility towards the corresponding moral foundations. We expected that the two categories of respondents targeted would score differently on MFQ. We awaited that representatives of the human rights NGOs pursuing a liberal/left agenda would gain low scores on the conservative moral foundations of loyalty/betrayal, authority/ subversion, and sanctity/degradation. The data ${ }^{7}$ presented in Figure 1 and Table 1 indicate that our findings replicated the survey responses from the United States. Members of the general public in Slovakia had similar scores to American conservatives while the representatives of human rights NGOs scored very much like the American liberals.

Figure 1 The moral foundations of the general public and NGOs in Slovakia General Public NGOs

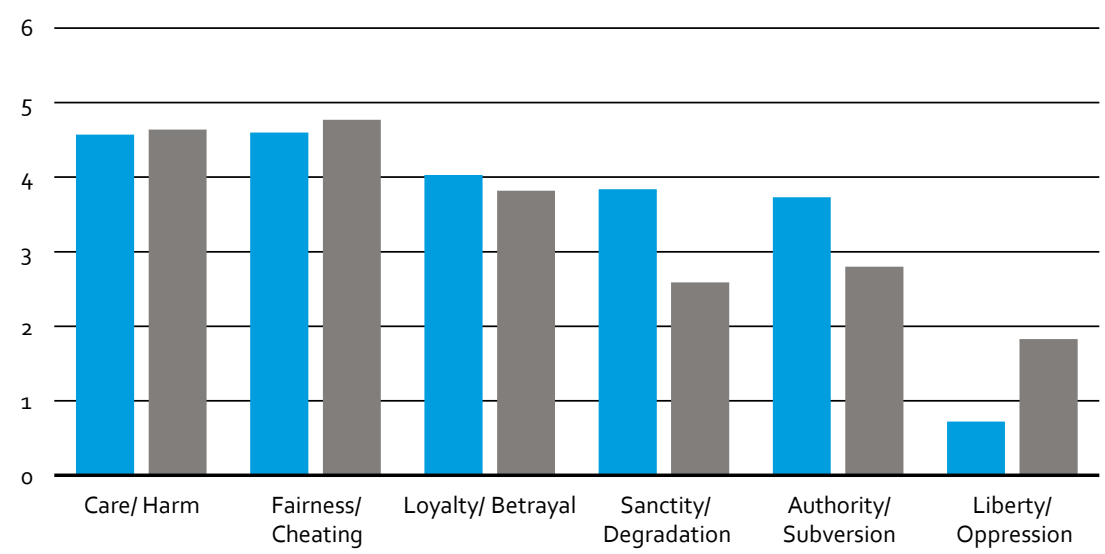

Source: Findor, Madarová, \& Ostertágová (2015)

7 Please, see Findor, Madarová, \& Ostertágová (2015) for a detailed description of the data set. 
Table 3 The moral foundations of the general public and NGOs in Slovakia

\begin{tabular}{|c|c|c|c|c|c|c|c|c|c|c|c|c|}
\hline \multirow{2}{*}{\multicolumn{2}{|c|}{ Care }} & \multicolumn{3}{|c|}{ Fairness } & \multicolumn{2}{|l|}{ Loyalty } & \multicolumn{2}{|c|}{ Sanctity } & \multicolumn{2}{|c|}{ Authority } & \multicolumn{2}{|l|}{ Liberty } \\
\hline & & Harm & \multicolumn{2}{|c|}{ Cheating } & \multicolumn{2}{|c|}{ Betrayal } & \multicolumn{2}{|c|}{ Degradation } & \multicolumn{2}{|c|}{ n Subversion } & \multicolumn{2}{|c|}{ Oppression } \\
\hline & $\begin{array}{l}\text { General } \\
\text { Public }\end{array}$ & I NGOs & $\begin{array}{l}\text { General } \\
\text { Public }\end{array}$ & al NGOs & $\begin{array}{l}\text { s General } \\
\text { Public }\end{array}$ & NGOs & $\begin{array}{l}\text { s General } \\
\text { Public }\end{array}$ & NGOs & $\begin{array}{l}\text { s General } \\
\text { Public }\end{array}$ & NGOs & $\begin{array}{l}\text { s General } \\
\text { Public }\end{array}$ & NGO \\
\hline $\begin{array}{l}M \\
\text { (SD) }\end{array}$ & $\begin{array}{l}4.57 \\
(0.74)\end{array}$ & $\begin{array}{l}4.64 \\
(0.70)\end{array}$ & $\begin{array}{l}4.60 \\
(0.61)\end{array}$ & $\begin{array}{l}4.77 \\
(0.53)\end{array}$ & $\begin{array}{l}4.03 \\
(0.62)\end{array}$ & $\begin{array}{l}3.82 \\
(0.72)\end{array}$ & $\begin{array}{l}3.84 \\
(1.00)\end{array}$ & $\begin{array}{l}2.59 \\
(0.83)\end{array}$ & $\begin{array}{l}3.73 \\
(0.80)\end{array}$ & $\begin{array}{l}2.80 \\
(0.73)\end{array}$ & $\begin{array}{l}0.72 \\
(0.68)\end{array}$ & $\begin{array}{l}1.83 \\
(1.00)\end{array}$ \\
\hline $\mathrm{F}$ & 0.511 & & $4.844 *$ & & $92.161 *$ & **** & $95.200 *$ & & $82.093 *$ & & 136.66 & $2 * * *$ \\
\hline \multicolumn{13}{|c|}{$* p \leq 0.05 ; * * p \leq 0.01 ; * * * p \leq 0.001$} \\
\hline \multicolumn{13}{|c|}{$\mathrm{M}$ - mean; SD - standard deviation; F-F-test results } \\
\hline
\end{tabular}

Source: Findor, Mad'arová, \& Ostertágová (2015)

Besides getting the basic validation data for MFQ we expected that the two categories targeted would have different scores on MFQ and that they would also choose different answers in a Political Attitudes Questionnaire (PAQ). PAQ contained nine items, one of them measuring attitudes towards revised recent amendment of the Act on the Assistance in Material Need (2013) which made the eligibility conditional upon fulfilling an "activity/merit requirement" - the beneficiaries were expected to work for public/community projects in order to receive the assistance. Figure 2 presents a striking difference in attitudes towards the conditionality of assistance in material need. $75 \%$ of respondents form the general public agreed with the statement that "only those individuals who are actively making an effort to improve their situation should be eligible to claim assistance in material need", while $80 \%$ of the respondents from human rights NGOs agreed with the statement that "all individuals should be eligible to claim assistance in material need because it is the duty of the state to guarantee minimal conditions for survival and human dignity".

8 These response alternatives may not appear equivalent - they do not seem to be equally justified. A closer examination reveals that the former is justified by activity of the beneficaries while the Aclor is justifed by the duty of the state to guarantee minimal conditions for suvival and human dignity. from making far-reaching conclusions, although the uncovered differences are significant: Pearson's Chi-square test result is 81.1789 , the $\mathrm{P}$ value is 0 , and this result is significant at $\mathrm{p}<0.05$.

Coincidentally, in September 2014, FOCUS research agency conducted a representative sample survey $(n=1043)$ for the Milan Šimečka Foundation, in which they also asked the respondents about their attitudes towards the conditionality of the assistance in material need. Their survey, presented in Figure 3, brought similar results as our study: $81 \%$ people agreed or partly agreed that the recipients should work off their basic assistance (Milan Šimečka Foundation, 2014). 
Figure 3 Agreement/disagreement with the provision that people in material need should work off their basic assistance

I agree. People should work off their basic assistance.

I partly agree. People should probably work off their basic assistance.

I partly disagree. People should probably receive their basic assistance

without further conditions.

I disagree. People should certainly receive their basic assistance

without further conditions.

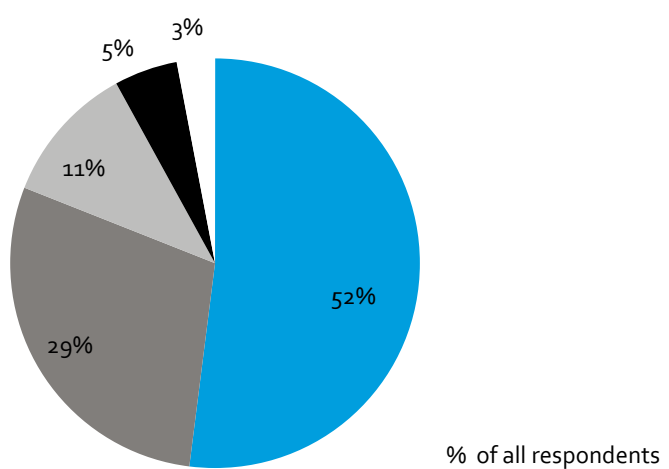

Source: Milan Šimečka Foundation (2014)

These findings relate to previously mentioned concept of homo reciprocans. A vast majority of respondents in both surveys agreed with the statements about the conditionality of assistance in material need, which stressed the importance of the deservingness of beneficiaries and the principle of reciprocity as fundamental for the fairness of the assistance (redistribution). Jesse Graham and his colleagues refer to this moral persuasion according to which "rewards are distributed in proportion to inputs and deservingness" as the fairness in tuition of equity (Graham, Iyer, \& Meindl, 2013). Haidt, referring to the same fairness intuition, prefers the term proportionality (Haidt, 2012; Haidt, 2013b) The minority of respondents who disagreed with the conditionality of assistance in material need made their moral judgements according to the principle or fairness intuition of equality, which stresses the neediness of assistance (redistribution) recipients and the equal opportunity to reach similar outcomes (Graham, Iyer, \& Meindl, 2013; Haidt, 2012; Haidt, 2013b). These fundamentally different versions of fairness were the main reason to add another dimension - liberty/oppression - to the Moral Foundation Questionnaire to capture the fairness intuition of equality because the original dimension fairness/cheating reflected predominantly the fairness intuitions of equity/pro- portionality (Haidt, 2012). This additional sixth foundation is computed from the scores of the original five moral foundations obtained by MFQ (its Slovak version as well).

It is important to add that such deservingness judgements, which underline our notion of fairness, can have far-reaching repercussions when combined with out-group hostility and ethnic/racial prejudice. As Peter Drál convincingly demonstrates, the Roma in Slovakia were increasingly represented as "lazy" in public policy formulation, the media and the political discourse (Drál', 2009). Drál' proposes the term "ethnicization of laziness" to draw attention to the confluence of ethnic stereotyping and prejudice feeding into out-group hostility.

The different moral intuitions about fairness can lead to value conflicts reflected in those negative welfare attitudes towards the undeserving recipients which build the necessary bulk of public opinion to support the political programmes of welfare chauvinism. In the upcoming sections I am going to introduce two different approaches to shifting welfare attitudes in more inclusive, more equal and less extreme directions.

\section{SHIFTING THE DIRECTION AND REDUCING THE POLARISATION OF WELFARE ATTITUDES}

By capturing the plurality of moral judgements, Moral Foundations Theory might be well positioned to devise interventions to effectively shift attitudes towards more progressive welfare policies and provisions. There are several studies which provide convincing indications of a promising future trend.

Even though protection of the environment is not among the most protracted political issues in Slovakia, in the United States environmental attitudes delineate one of the most polarising political battlefields. Matthew Feinberg and Robb Willer attempted to find out how knowledge of moral foundations could convince more people about the need to protect the environment. Since environmental issues were viewed in moral terms (care/harm) only by American liberals, they attempted to find out how the American conservatives might become more accepting of the protection of the environment. In one of their experiments, Feinberg and Willer reframed pro-environmental stances in terms of purity (the moral foundation of sanctity/degradation) to which conservative respondents were expected to be more responsive. This reframing successfully reduced the gap between the environmental attitudes of liberal and conservatives and make environmental protection an almost equally acceptable policy position for both opposite groups (Feinberg \& Willer, 2012). 
In a similar fashion, a team of researchers led by Martin V. Day set out to explore the viability of shifting a wider array of political attitudes by using Moral Foundations Theory (Day, Fiske, Downing, \& Trail, 2014). Day and his colleagues attempted to discover whether the liberal and conservative mora foundation framings of issues (immigration, environment, economic market, social programmes, education) would lead to pro-attitudinal ("entrenching") or counter-attitudinal ("persuasion") change in the direction of attitudes. The "entrenching" hypothesis was confirmed for both liberal and conservative stances. Interestingly, the "persuasion" hypothesis was confirmed only for liberal stances - "conservative-relevant moral frames of liberal issues increased conservatives' liberal attitudes" (Day, Fiske, Downing, \& Trail, 2014, p. 1559). As Table 2 demonstrates, the reframing of welfare assistance (social programmes) in conservative moral terms opens up new unchartered territory for reaching social accord and legitimacy.

Table 4 The liberal moral foundation framing of social programmes

\begin{tabular}{lll}
\hline Social Programmes & \\
\hline Harm & $\begin{array}{l}\text { We must prevent harm to those less } \\
\text { fortunate than us. }\end{array}$ & $\begin{array}{l}\text { Even poor people need society to } \\
\text { care for them. }\end{array}$ \\
\hline Fairness & $\begin{array}{l}\text { It is only fair that government } \\
\text { provides for those less fortunate. }\end{array}$ & $\begin{array}{l}\text { If we help the poor, they will } \\
\text { reciprocate. }\end{array}$ \\
\hline In-group & Poor people are loyal Americans. & $\begin{array}{l}\text { We are all part of the same country, } \\
\text { no matter how much money we } \\
\text { make. }\end{array}$ \\
\hline Authority & $\begin{array}{l}\text { All people deserve respect, no } \\
\text { matter their income level. }\end{array}$ & $\begin{array}{l}\text { If we respect poor people, they will } \\
\text { respect us. }\end{array}$ \\
\hline Purity & $\begin{array}{l}\text { Every human life is sacred, no } \\
\text { matter how much money they } \\
\text { make. }\end{array}$ & $\begin{array}{l}\text { Even poor people are pure at their } \\
\text { core. }\end{array}$ \\
\hline
\end{tabular}

Source: Day, Fiske, Downing, \& Trail (2014), Methodology Appendix

Day and his colleagues also presented evidence that reframing conservative stances on issues (including social programmes) in liberal moral terms did not persuade liberals - the conservative attitudes of liberals did not increase (Day, Fiske, Downing, \& Trail, 2014, p. 1559).
Table 5 The conservative moral foundation framing of social programmes

\section{Social Programmes}

\begin{tabular}{lll}
\hline Harm & $\begin{array}{l}\text { Sometimes social programmes can } \\
\text { be harmful because they can prevent } \\
\text { people from helping themselves. }\end{array}$ & $\begin{array}{l}\text { By wasting money, those who } \\
\text { overuse social services harm the } \\
\text { overall system. }\end{array}$ \\
\hline Fairness & $\begin{array}{l}\text { It is unfair that some people take } \\
\text { advantage of social programmes. }\end{array}$ & $\begin{array}{l}\text { It is not fair that some people's hard } \\
\text { work gives other people a free ride. }\end{array}$ \\
\hline In-group & $\begin{array}{l}\text { Hard working citizens that support } \\
\text { themselves are loyal Americans. }\end{array}$ & $\begin{array}{l}\text { Living off the system is not the } \\
\text { American way. }\end{array}$ \\
\hline Authority & $\begin{array}{l}\text { Those who work hard and fend for } \\
\text { themselves deserve more respect } \\
\text { than those who do not. }\end{array}$ & $\begin{array}{l}\text { Authorities should not allow people } \\
\text { to live off the system. }\end{array}$ \\
\hline Purity & $\begin{array}{l}\text { Hard earned incomes are sacred } \\
\text { and should not be given away by } \\
\text { government. }\end{array}$ & $\begin{array}{l}\text { The hands of social services are dirty } \\
\text { with those who live off the system. }\end{array}$ \\
& & \\
\hline
\end{tabular}

Source: Day, Fiske, Downing, \&Trail (2014), Methodology Appendix

According to Francisco José León, successful welfare policies should not offend our "robust and unchanging dispositions. This is not to give into fatalism, as such predispositions do not necessarily imply a particular type of policies. It is only a question of accepting factors that constrain us when we want to design our institutions" (León, 2012, p. 212). Reframing welfare policies in moral terms that a majority of the citizens understand does not necessarily lead to fatal acceptance of predisposed moral intuitions. Neither does a counter-attitudinal shift in attitudes necessarily signal the threat of rhetorical manipulation. Tapping into moral foundations to improve the acceptability of divisive welfare policies can serve as a bridge between different segments of society, helping them to undertake the social transformation and yet to remain true to themselves, to their "innermost" values and intuitions.

As I mentioned above, Haidt's elephant rider metaphor was criticized for the primacy it gave to intuition in the formation of moral judgment (Bloom, 2013; Greene, 2013). I am going to mention only two critics of Haidt's intuitivism whose work could have implications for designing interventions aimed at influencing moral reasoning. Paul Bloom, as a developmental psychologist, made a strong case against moral intuitivism by claiming that

"[T]he right theory of our moral lives has two parts. It starts with what we are born with, and this is surprisingly rich: babies are moral animals, 
equipped by evolution with empathy and compassion, the capacity to judge the actions of others, and even some rudimentary understanding of justice and fairness. But we are more than just babies. A critical part of our morality - so much of what makes us human - emerges over the course of human history and individual development. It is the product of our compassion, our imagination, and our magnificent capacity for reason" (Bloom, 2013, p. 218).

For Bloom, moral deliberation and impartiality as prerequisites for moral reasoning are directly linked to moral progress. As he asserts, our capacity for moral reasoning and deliberation enabled us to make "moral discoveries, such as the wrongness of slavery" (Bloom, 2013, p. 207). Bloom champions the idea of "educated intuitions" (Sauer, 2012) - that our reasoning capacities can be used to navigate our intuitions: "we can use our intelligence to manage our information and constrain our options, allowing our better selves to overcome those gut feelings and appetites that we believe we would be better off without" (Bloom, 2013, p. 130).

In a similar fashion, Joshua Greene, a leading researcher in the field of moral cognition, defends in his work the significance of reasoning against the dominance of intuitions in moral judgement (Greene, 2013). Like Bloom, Greene is a firm believer in the capacities of reasoning, which could be used to "confront ignorance" and manage the intuitive drives of our gut feelings and judgements. Greene refers to a study by Philip M. Fernbach and his colleagues, which is illustrative of how the ignorance and extremity of attitudes can be challenged effectively (Fernbach, Rogers, Fox, \& Sloman, 2013). The authors begin with an assumption that people usually know less than they think they do especially about complex policy issues. Asking participants to provide a mech anistic explanation of a policy undermined their illusion of explanatory depth decreased confidence in their own opinions and most importantly decreased the extremity of their opinions. The mechanistic explanation task consisted in asking participants how a particular policy works in a causal, step-by-step manner. Interestingly, Fernbach and his colleagues did not observe this effect when participants were asked to enumerate reasons for their policy preferences but only when they were asked to generate a mechanistic explanation (Fernbach, Rogers, Fox, \& Sloman, 2013). The latter could lead to a novel way of conducting public discussion and deliberation, one in which the polarised policy issues (including welfare provisions such as assistance in material need) could evoke more moderate opinions and attitudes.

\section{CONCLUSION}

In this article I attempted to interconnect two developed interdisciplinary research programmes. The endeavour is just beginning and it remains to be seen whether and how the findings of welfare attitudes research on issues such as income inequality, the cleavage between religious and secular individuals and reciprocity as the defining element of fairness translate into moral foundations analysis and thinking about the formation of political and ideological preferences. I hope I provided some arguments so as such endeavour cannot be dismissed easily.

The last two sections of the article discuss the added value of MFT and related research programmes - their ability to intervene, to shift attitudes and to make them less extreme. Both intervention approaches I introduced are complementary. There is no silver bullet for attitude change toward more moderation and inclusiveness. As was clearly visible, effective interventions must appeal both to intuitions and reasoning. A less activist reader may wonder why there is such a prominent place reserved for interventionist research. A quote presumably attributed to one of the parents of social psychology, Kurt Lewin, might be of assistance here: "If you want truly to understand something, try to change it" (Tolman, Cherry, van Hezewijk, \& Lubek, 1996, p. 31). Of course, the risks can become high, especially in disciplinary milieus which are much more reserved to the idea of intertwining research and social change (intervention), compared to social psychology. On the other hand, the better case scenario is what another great social psychologist, Timothy D. Wilson, had in mind when he devised his "do not ask, cannot tell" principle (Wilson, 2012). We might happen to understand the inflicted change without having access to all data to build a theory comprehensive and robust enough to explain it.

\section{REFERENCES}

Arts, W., \& Gelissen, J. (2001). Welfare States, Solidarity and Justice Principles: Does the

Type Really Matter? Acta Sociologica, 44(4), 283-299. doi:10.1080/00016990152696385 Bloom, P. (2013). Just Babies: The Origins of Good and Evil. New York: Crown Publishers.

Bocian, K., \& Wojciszke, B. (2014). Self-Interest Bias in Moral Judgments of Others' Actions. Personality and Social Psychology Bulletin, 40(7), 898-909. doi:10.1177/0146167214529800

Bommes, M., \& Geddes, A. (2000). Immigration and Welfare: Challenging the Borders of the Welfare State. London: Routledge.

Brady, D., \& Finnigan, R. (2014). Does Immigration Undermine Public Support for Social Policy? American Sociological Review, 79(1), 17-42. doi:10.1177/0003122413513022

Brooks, C., \& Manza, J. (2007). Why Welfare States Persist: The Importance of Public Opinion in Democracies. Chicago: University Of Chicago Press. 
Day, M., Fiske, S., Downing, E., \& Trail, T. (2014). Shifting Liberal and Conservative Attitudes Using Moral Foundations Theory. Personality and Social Psychology Bulletin 40(12), 1559-1573. doi:10.1177/0146167214551152

Ditto, P., \& Koleva, S. (2011). Moral Empathy Gaps and the American Culture War. Emotion Review, 3(3), 331-332. doi:10.1177/1754073911402393

Drál', P. (2009). Lenivost' ako 'esencia' rómskej etnickej identity: kritická analýza diskurzu slovenskej sociálnej politiky. In P. Drál' \& A. Findor (Eds.), Ako skúmat' národ: devät' štúdií o etnicite a nacionalizme (pp. 189-224). Brno: Tribun EU.

Edlund, J. (1999). Trust in Government and Welfare Regimes: Attitudes to Redistribution and Financial Cheating in the USA and Norway.European Journal of Political Research, 35(3), 341-370. doi:10.1111/1475-6765.00452

Ervasti, H. (2012). Who Hates the Welfare State? Criticism of the Welfare State in Europe. In H. Ervasti, J. Goul Andersen, \& T. Fridberg, The Future of the Welfare State: Social Policy Attitudes and Social Capital in Europe (pp. 231-248). Cheltenham: Edward Elgar Publishing Ltd.

Feinberg, M., \& Willer, R. (2012). The Moral Roots of Environmental Attitudes. Psychological Science, 24(1), 56-62. doi:10.1177/0956797612449177

Fernbach, P., Rogers, Fox, C., \& Sloman, S. (2013). Political Extremism Is Supported by an Illusion of Understanding. Psychological Science, 24(6), 939-946. doi:10.1177/0956797612464058

Findor, A., Mad’arová, Z., \& Ostertágová, A. (2014). Dotazník morálnych základov: adaptácia a využitie v kontexte Slovenskej republiky. In L. Bomba, E. Kövérová, \& M. Smrek (Eds.), Fenomén moci a sociálne nerovnosti. Zbornik príspevkov z nultého ročníka konferencie doktorandov a mladých vedeckých pracovníkov (pp. 55-80). Bratislava: Univerzita Komenského. Retrieved from https://mocnerovnosti.files. wordpress.com/2014/05/fenomen_moci_a_socialne_nerovnosti_0.pdf

Findor, A., Madarová, Z., \& Ostertágová, A. (2015). Morálne základy sporu o sociálnu spravodlivost' na Slovensku. In T. Podolinská \& T. Hrustič (Eds.), Rómovia v majoritnej spoločnosti (pp. 46-64). Bratislava: Veda. (in press)

Frey, R., \& Morris, C. (1993). Value, Welfare, and Morality. Cambridge: Cambridge University Press.

Graham, J., Haidt, J., Koleva, S., Motyl, M., Iyer, R., Wojcik, S. P., \& Ditto, P. H. (2013). Moral Foundations Theory: The Pragmatic Validity of Moral Pluralism. In P. Devine (Ed.), P. Devine \& A. Plant, Advances in Experimental Social Psychology: Volume 47 (Vol. 47, pp. 55-130). New York: Academic Press Inc.

Graham, J., lyer, R., \& Meindl, P. (2013). The Psychology of Economic Ideology: Emotion, Motivation, and Moral Intuition. Demos, 1-16. Retrieved from http://www.demos.org/ sites/default/files/publications/Graham.pdf

Graham, J., Nosek, B. A., Haidt, J., lyer, R., Koleva, S., \& Ditto, P. H. (2011). Mapping the Moral Domain. Journal of Personality and Social Psychology, 101(2), 366-385. doi:10.1037/a0021847

Graham, J., Nosek, B., \& Haidt, J. (2012). The Moral Stereotypes of Liberals and Conservatives: Exaggeration of Differences across the Political Spectrum. PLOS ONE, 7(12). doi:10.1371/journal.pone.0050092

Greene, J. (2013). Moral Tribes. New York: Penguin Press.

Greve, B. (2008). What is Welfare? Central European Journal of Public Policy, 2(1), 50-73.
Haidt, J. (2005). The Happiness Hypothesis: Finding Modern Truth in Ancient Wisdom. New York: Basic Books.

Haidt, J. (2012). The Righteous Mind: Why Good People Are Divided by Politics and Religion New York: Random House Inc.

Haidt, J. (2013a). Moral Psychology for the Twenty-First Century.Journal of Moral Education 42(3), 281-297. doi:10.1080/03057240.2013.817327

Haidt, J. (2013b). Of Freedom and Fairness. Democracy: A Journal of Ideas, (28), 38-50. Retrieved from http://www.democracyjournal.org/28/of-freedom-and-fairness. php?page=all

Haidt, J., Graham, J., \& Joseph, C. (2009). Above and Below Left-Right: Ideological Narratives and Moral Foundations. Psychological Inquiry, 20(2-3) 110-119. doi:10.1080/10478400903028573

Haidt, J., \& Joseph, C. (2004). Intuitive Ethics: How Innately Prepared Intuitions Generate Culturally Variable Virtues. Daedalus, 133(4), 55-66. doi:10.1162/0011526042365555

Iyer, R., Koleva, S., Graham, J., Ditto, P., \& Haidt, J. (2012). Understanding Libertarian Morality: The Psychological Dispositions of Self-Identified Libertarians. PLOS ONE 7(8). doi:10.1371/journal.pone.0042366

Jo, N. (2011). Between the Cultural Foundations of Welfare and Welfare Attitudes: The Possibility of an In-Between Level Conception of Culture for the Cultural Analysis of Welfare. Journal of European Social Policy, 21(1), 5-19. doi:10.1177/0958928710385736

Kahneman, D. (2011). Thinking, Fast and Slow. New York: Farrar, Straus \& Giroux.

Koleva, S., Graham, J., Iyer, R., Ditto, P., \& Haidt, J. (2012). Tracing the Threads: How Five Moral Concerns (Especially Purity) Help Explain Culture War Attitudes. Journal of Research in Personality, 46(2), 184-194. doi:10.1016/j.jrp.2012.01.006

Leon, F. (2012). Reciprocity and Public Support for the Redistributive Role of the State. Journal of European Social Policy, 22(2), 198-215. doi:10.1177/0958928711433657

Mau, S. (2003). The Moral Economy of Welfare States: Britain and Germany Compared. London: Taylor \& Francis, Inc

Milan Šimečka Foundation (2014). Ako na chudobu: prieskum verejnej mienky na Slovensku o vnimani chudoby. Retrieved from: http://www. milansimecka.sk/ akonachudobu/pdf/prieskum-verejnej-mienky.pdf

Petersen, M. B., Sznycer, D., Cosmides, L., \& Tooby, J. (2012). Who Deserves Help? Evolutionary Psychology, Social Emotions, and Public Opinion about Welfare. Political Psychology, 33(3), 395-418. doi:10.1111/j.1467-9221.2012.00883.x

Rawls, J. (1971). A Theory of Justice. Cambridge, MA: Harvard University Press.

Reeskens, T., \& van Oorschot, W. (2012). Disentangling the 'New Liberal Dilemma': On the Relation between General Welfare Redistribution Preferences and Welfare Chauvinism. International Journal of Comparative Sociology, 53(2), 120-139. doi:10.1177/0020715212451987

Roosma, F., van Oorschot, W., \& Gelissen, J. (2014). The Weakest Link in Welfare State Legitimacy: European Perceptions of Moral and Administrative Failure in the Targeting of Social Benefits. International Journal of Comparative Sociology, 55(6), 489-508. doi:10.1177/0020715214565932

Saver, H. (2012). Educated Intuitions. Automaticity and Rationality in Moral Judgement. Philosophical Explorations, 15(3), 255-275. doi:10.1080/13869795.2012.706822 
Scheepers, P., Gijsberts, M., \& Coenders, M. (2002). Ethnic Exclusionism in European Countries. Public Opposition to Civil Rights for Legal Migrants as a Response to Perceived Ethnic Threat.European Sociological Review, 18(1), 17-34. doi:10.1093/ esr/18.1.17

Schmidt, A., \& Spies, D. (2014). Do Parties 'Playing the Race Card' Undermine Natives' Support for Redistribution? Evidence From Europe. Comparative Political Studies, 47(4), 519-549. doi:10.1177/0010414013488542

Schumacher, G., \& van Kersbergen, K. (2014). Do Mainstream Parties Adapt to the Welfare Chauvinism of Populist Parties? Party Politics, 1-13. doi:10.1177/1354068814549345

Shafir, E. (Ed.). (2013). The Behavioral Foundations of Public Policy. Princeton: Princeton University Press.

Shionoya, Y. (2005). Economy and Morality: The Philosophy of the Welfare State. London: Edward Elgar Publishing Ltd.

Sinnott-Armstrong, W. (2008). Moral Psychology: The Cognitive Science of Morality: Intuition and Diversity: Volume 2. Cambridge, MA: Bradford Books.

Stegmueller, D., Scheepers, P., Rossteutscher, S., \& de Jong, E. (2011). Support for Redistribution in Western Europe: Assessing the role of religion. European Sociological Review, 28(4), 482-497. doi:10.1093/esr/jcr011

Stewart, M. (Ed.). (2012). The Gypsy 'Menace': Populism and the New Anti-Gypsy Politics. London: Hurst \& Company.

Svallfors, S. (Ed.). (2012). Contested Welfare States: Welfare Attitudes in Europe and Beyond. Stanford, CA: Stanford University Press.

Tolman, C. W., Cherry, F., van Hezewijk, R., \& Lubek, I. (Eds.). (1996). Problems of Theoretical Psychology. Concord, ON: Captus Press.

Van der Waal, J., de Koster, W., \& van Oorschot, W. (2013). Three Worlds of Welfare Chauvinism? How Welfare Regimes Affect Support for Distributing Welfare to Immigrants in Europe. Journal of Comparative Policy Analysis: Research and Practice, 15(2), 164-181. doi:10.1080/13876988.2013.785147

Van Oorschot, W. (2006). Making the Difference in Social Europe: Deservingness

Perceptions among Citizens of European Welfare States. Journal of European Social Policy, 16(1), 23-42. doi:10.1177/0958928706059829

Wilson, T. D. (2011). Redirect: The Surprising New Science of Psychological Change. New York: Little, Brown and Company. 